
\title{
Al'Adôlah \\ URGENSI INTEGRASI DAN IMPLEMENTASI MASLAHAH DALAM PROSES MEDIASI
}

\author{
Moh. Ali \\ State Islamic University of Sunan Ampel Surabaya \\ alialwahid07@gmail.com
}

\begin{abstract}
Mediation in the judiciary in Indonesia is still new, cases that are in court must be handled professionally, such family case. This has claimed many victims, both material and life. This study is the orientation of mediation rules and its implications for the settlement of civil cases in the Religious Courts. There are three important aspects that will be discuss in this research, these are: Juridicalphilosophical foundation for integrating mediation in the proceedings at the Religious Courts, The implimentation of mediation in the Religious Courts, maslahah analysis on the integration of mediation in the proceedings at the Religious Courts. This research is socio-legal qualitative research, because it is closely related to the study of the texts in the legislation; by using a state approach and focusing on legal norms and the hierarchy of the rules. The result of this research reveals that; (1) The juridical-philosophical foundation integrated with mediation in the proceedings at the Religious Courts, which is based on PERMA No. 1 of 2008, the mediator of the Religious Court then integrates into facilitative mediation and transformative mediation model. (2) Mediation conducted by the Religious Courts does not only discuss about problems that occur, but also discuss the root of the problem and making a solutions that cannot only be completed in the trial, and also bring benefits to the disputing parties. (3) In general, the integration of mediation in proceedings process in the Religious Court is in Maslahah's perspective, with the existence of Maslahah, by utilizing Al-Maslahah AlMu'tabarah, such as; by hastening the implementation of divorce (wife), as a form of state protection to prevent the emergence of suffering and the madharat of both parties. Protection of the soul, to avoid the tyranny of others. Become a catalyst so that the parties become easy to live and protracted problems to realize the path of peace. Protection of human dignity, by making a decision to cancel the marriage for the Plaintiff who has given a false identity.
\end{abstract}

Keywords: Mediation, Court, Maslahah

\section{Pendahuluan}

Dalam kehidupan masyarakat, konflik yang terjadi meliputi struktur atau sistem tindakan, kata-kata dan sikap yang mengganggu atau menyebabkan kerugian baik 
secara fisik, psikis, dan sosial dan/atau menutup kemungkinan orang lain untuk mencapai potensi diri sepenuhnya sebagai manusia. Seharusnya antar individu dan kelompok masyarakat tersebut hidup bersama-sama dan saling berdampingan, tanpa konflik dan penuh kedamaian. Karena di dalam individu manusia menginginkan hal yang benar dan maslahah, namun disisi lain manusia bersifat agresif.

Proses penyelesaian perselisihan atau konflik dari dua pihak saling menguntungkan, maka dibutuhkan penyelesaian secara hukum dalam Peradilan. Hal inilah yang menjadi salah satu sebab hukum diperlukan untuk menjamin ketertiban hidup manusia yang saling berkepentingan dapat dilakukan dengan cara negosiasi. Tetapi negosiasi bukan berarti salah satu pihak harus mengalah, dan juga bukan berarti harus menang dengan mengalahkan pihak lain. Negosiasi merupakan kesediaan dan kemauan untuk mencari opsi secara kreatif untuk menemukan solusi yang dapat memuaskan bagi kedua belah pihak.

Secara historis, penyelesaian konflik melalui mediasi pernah dilaksanakan oleh Nabi Muhammad s.a.w., baik sebelum menjadi Rasul maupun setelah menjadi Rasul. Proses penyelesaian konflik dapat ditemukan dalam peristiwa peletakan kembali Hajar Aswad dan perjanjian Hudaibiyah. Kedua peristiwa ini dikenal baik oleh kaum Muslimin diseluruh dunia, dan karena itu diterima secara umum. Peletakan kembali Hajar Aswad dan perjanjian Hudaibiyah memiliki nilai dan strategi resolusi konflik terutama mediasi dan negoisasi, sehingga kedua peristiwa ini memiliki perspektif yang sama yaitu mewujudkan perdamaian. ${ }^{1}$

Kesuksesan Muhammad s.a.w., di dalam perjanjian Hudaibiyah itu karena dilandasi dengan beberapa prinsip mediasi antara lain; sikap negosiasi, sikap kompromi, memposisikan sama para pihak, dan menghargai kesepakatan. Muhammad s.a.w., telah melakukan negosiasi dengan pimpinan kaum kafir Quraisy agar mereka bersedia berdamai dengan kaum muslimin yang diwakili oleh Muhammad s.a.w. Dalam pada itu, Nabi Muhammad s.a.w. telah berusaha meyakinkan kaum kafir Quraisy agar bersedia duduk satu meja dengan kaum Muslimin, sebelumnya dua kelompok yang selalu bertikai.

Berdasarkan uraian di atas, maka dalam proses mediasi kemampuan meyakinkan para pihak yang bersengketa untuk bersedia duduk bersama merupakan langkah yang menentukan keberhasilan proses mediasi. Selanjutnya mediator dan para pihak harus memahami bahwa penyelesaian sengketa melalui mediasi tidak mungkin mampu memenuhi seluruh tuntutannya. Sikap saling memahami, memberi dan menerima dari kedua belah pihak harus dikedepankan sehingga tidak ada yang merasa dirugikan satu sama lain. Dengan demikian konflik harus diselesaikan secara bijaksana, tida terkecuali permasalahan dalam lingkup peradilan.

${ }^{1}$ Hamadi Redissi dan Jon-Erik Lane, "Does Islam Partivide a Theory of Violence", dalam Amelie Blom, Laetitia Bucaille Dab Luis Martinez, The Enigma of Iaslamits Violence (New York: Columbia University Press, 2007),. 48. Baca Syahrisal Abbas, Mediasi dalam Hukum Syariah, Hukum Adat, \&o Hukum Nasional (Jakarta: Kencana, 2011), 166. 
Moh. Ali, Urgensi Politik dan Implementasi Maslahah...

Lembaga peradilan mempunyai peranan yang penting dan menentukan dalam konteks penegakan hukum dan keadilan bagi masyarakat. Tuntutan terhadap peranan yang dimainkan oleh lembaga Peradilan semakin meningkat sejalan dengan kompleksitas perkara yang muncul ditengah-tengah masyarakat khususnya berkaitan dengan persoalan perdata seperti perceraian, harta bersama, sengketa harta waris dan lain sebagainya, sehingga masyarakat mendapatkan kepastian hukum atas persoalan yang mereka hadapi.

Sejak berlakunya ketentuan pengintegrasian mediasi dalam Peradilan di Indonesia yang tergolong baru, sedikit atau banyak telah mendatangkan manfaat baik yang kembali kepada para pihak yang berperkara maupun kepada lembaga Peradilan sendiri, terlepas apakah mediasi itu berhasil dengan perdamaian atau tidak. Setidaknya mediasi dapat menjadi instrumen yang efektif dalam mengatasi masalah penumpukan perkara di Peradilan juga mengurai kompleksitas persoalan yang diajukan oleh pihak berperkara serta memperkuat dan memaksimalkan fungsi lembaga Peradilan dalam menyelesaikan sengketa, meskipun belum berharap banyak untuk efektifitasnya, karena keterbatasanketerbatasan yang dihadapi, misalnya kesadaran masyarakat pencari keadilan mengenai urgensi mediasi, kuantitas dan kualitas mediator serta ketersediaan sarana pendukung yang memadai, juga cara pandang masyarakat terhadap dunia persidangan atau peadilan.

Salah satu pelaksana kekuasaan kehakiman yang berwenang menyelesaikan perkara perdata, Pengadilan Agama misalnya, ${ }^{2}$ dalam mengimplementasikan mediasi dalam proses beracara disamping harus sejalan dengan peraturan dan perundangundangan yang terkait juga tidak boleh lepas dari prinsip-prinsip hukum Islam, bahkan dalam perspektif maslahah memungkinkan adanya upaya penyelesaian perkara dengan menggunakan metode multi doors (berbagai cara) sehingga hal tersebut dapat menghasilkan solusi yang lebih efektif dan efisien serta terhindar dari nuansa formalitas birokrasi.

Penelitian ini dilakukan dalam paradigma hukum normatif dan empiris dalam perspektif maslahah. Karena meskipun shara' tidak menegaskan secara rinci tentang bagaimana seharusnya proses beracara dalam Peradilan dilakukan, namun perdamaian antar pihak yang berselisih merupakan maslahah, sementara konflik di antara mereka adalah madarat. Sebagaimana al-Shatibi, mengatakan bahwa shari'ah yang dimaksudkan oleh pencipta hukum (shari) ialah untuk mewujudkan kemaslahatan umat manusia. AlShatibi membagi maslahah ke dalam tiga tingkatan: Pertama, daruriyah, yaitu kemaslahatan yang menjadi acuan utama bagi shari'ah. Kedua, hajzyah, yaitu kemaslahatan yang tidak menyebabkan rusaknya tatanan sosial dan hukum, melainkan sebagai upaya untuk meringankan bagi pelaksanaan hukum. Ketiga, tahsiniyah, yaitu kemaslahatan yang memberikan perhatian terh.adap masalah estetika dan etika yang mungkin hadir pada

2 I Nengah Yuliana, Kompilasi Perundang-undangan Hukum Acara Peradilan dan Undan-undang Penegakan Hukum di Indonesia, 2004, 2. 
Al-‘adalah, Volume 22 Nomor 1 April 2019

setiap keadaan. ${ }^{3}$

Kategori tersebut, tidak lain adalah untuk mewujudkan kemaslahatan dalam kehidupan umat manusia di dunia maupun akhirat. ${ }^{4}$ Dengan demikian pengintegrasikan PERMA No. 1/2008 tentang mediasi ke dalam sistem peradilan harus mewujudkan maksud tersebut. Oleh karenanya penelitian ini dilakukan dan dirasa peting untuk dididkusikan. Mengingat kompleksitas persoalan hidup masyarakat saat ini semakin bervariasi dan tidak sedikit yang memerlukan jalan keluar sesegera mungkin,. Agar persoalan tersebut tidak merambat ke berbagai bidang kehidupa masyarakat lainnya Inti studi ini ialah orientasi kaidah-kaidah tentang mediasi dan implikasinya terhadap penyelesaian perkara perdata khususnya di lingkungan Peradilan.

\section{Metode Penelitian}

Pendekatan yang dipilih untuk melihat dan memecahkan permasalahan dalam penelitian ini peneliti menggunakan pendekatan filosofis normative, karena penelitian ini dilakukan dengan cara meneliti bahan-bahan pustaka atau data sekunder berkaitan dengan mediasi kemudian mengkaji pelaksanaan mediasi di Peradilan dalam perspektif maslahah. ${ }^{5}$ Sedangkan metode yang digunakan yakni deskriptif analisis terhadap kaidahkaidah dalam peraturan mediasi dan implementasinya di lingkup Peradilan. Metode penelitian deskriptif ini dipilih karena dapat menjelaskan suatu masalah yang bersifat kasuistik dengan cara menggambarkan kasus yang sedang diteliti berdasarkan hubungan antara teori dengan kenyataan di lapangan.

\section{Hasil Penelitian dan Pembahasan}

\section{Integrasi PERMA NO.1 Tahun 2008 di Lingkungan Peradilan Agama}

Dari hasil penelitian ini ditemukan bahwa, (1) Landasan yuridis-filosofis yang diintegrasikan mediasi dalam proses beracara di Peradilan Agama ialah dengan berlandaskan pada PERMA No. 1 Tahun 2008, mediator Peradilan Agama kemudian mengintegrasikan pada model mediasi facilitative mediation dan transformative mediation (2) Mediasi yang dilakukan Peradilan Agama tidak hanya membicarakan masalah yang sedang terjadi, akan tetapi juga akar dari permasalahan dan membuat perkiraanperkiraan tentang solusi yanng tidak hanya bisa selesai dalam persidangan saja akan tetapi juga membawa kebermanfaatan bagi pihak-pihak yang berselisih (3) Secara umum pengintegrasian mediasi dalam proses beracara di Peradilan Agama dalam perspektif maslahah, dari segi keberadaan maslahah, dengan memanfaatkan Al-Maslahah Al-Mu'tabarah yaitu, maslahah yang secara tegas diakui oleh syariat dan telah ditetapkan

${ }^{3} \mathrm{Abu}$ Ishaq al-Shatibi, al-Muwafaqat fi Usul al-Shari'ah (Beirut: Dar al-Kutub al-Ilmiyah, 2004), hlm. 23-24

4Suparman Usman, Hukum Islam: Asas-asas dan Pengantar Studi Hukum Islam dalam Tata Hukum Indonesia (Jakarta: Gaya Media Pratama, 2001), 65-66.

${ }^{5}$ Soerjono Soekanto dan Sri Mamudji, Penelitian Hukum Normatif Suatu Tinjanan Singkat, (Jakarta: Rajawali Press, 1999), dan Zainuddin Ali, Metode Penelitian Hukum (Jakarta: Sinar Grafika, 2009), 46-48. 
Moh. Ali, Urgensi Politik dan Implementasi Maslahah...

ketentuan-ketentuan hukum yang direalisasikan sebagai berikut: a. Dengan menyegerakan terlaksannya gugatan cerai penggugat (istri), sebagai bentuk perlindungan negara untuk mencegah timbulnya penderitaan dan mudlarat kedua belah pihak. Hal ini dilakukan agar setiap warga negara taat akan peraturan yang telah berlaku. b. Perlindungan terhadap jiwa, hikmah keberadaan syariah dengan aturannya melindungi jiwa manusia agar terhindar dari kezaliman orang lain. c. Menjadi katalisator agar pihak berperkara menjadi mudah untuk menjalani hidup dan masalah yang berlarut-larut maupun menghilangkan kesulitan yang selama ini dihadapi pihak berperkara yang akan menyulitkan siapa saja untuk mewujudkan jalan perdamaian. $\mathrm{d}$. Perlindungan terhadap kehormatan manusia, dengan membuat keputusan pembatalan pernikahan untuk Penggugat yang telah memberikan identitas yang salah kepada Pegawai Pencatat Nikah KUA.

\section{Implementasi PERMA NO.1 Tahun 2008 di lingkungan Peradilan Agama}

\section{Efektifitas Mediasi Dalam Penyelesaian Perkara}

Perkara permohonan cerai di Peradilan Agama Surabaya. Pada perkara ini mediasi mengalami kegagalan, Peradilan Agama Surabaya juga tidak serta merta hanya memepertimbangkan kegagalan mediasi yang dilakukan secara resmi oleh pihak Peradilan akan tetapi Peradilan juga mempertimbangkan usaha-usaha mendamaikan yang dilakukan oleh pihak keluarga sebagaimana yang diungkapkan kesemua saksi dari Pemohon maupun Termohon memberikan keterangan dihadapan Majelis Hakim dibawah sumpah, sebagai proses mendamaikan pihak-pihak yang berperkara, dalam proses pengambilan keputusan. Mediasi pada perkara ini yang berefek pada kegagalan disebabkan pihak Pemohon yang bersikukuh pada pendiriannya untuk bercerai dari Termohon karena masalah perselingkuhan yang dilakukan Pemohon terus menerus meskipun pihak Termohon memiliki kemampuan lebih dari wanita manapun untuk memaafkan perlaku Pemohon demi kebaikan anak-anak yang masih belum dewasa yang belum tentu mampu menghadapi perceraian kedua orang tuanya, pada perkara ini tidak hanya ditemukan masalah yang berlarut-larut sehingga jalan perdamaian maupun cita-cita untuk membangun rumah tangga yang sakinah, mawaddah, wa rahmah sulit untuk terwujud akan tetapi juga keingingan dari pihak Pemohon untuk segera berpisah dengan Termohon sudah berlarut-larut yang memuncak pada akhirnya pada sidang permohonan perceraian ini dan bukan karena pada proses mendamaikan atau usaha melakukan mediasi ataupun mediator tidak berkompeten untuk melakukan proses mediasi yang menyebabkan kegagalan.

Begitupun kegagalan mediasi terjadi di Peradilan Agama Sidoarjo dalam perkara Permohonan Ijin Pologami. Peradilan Agama pada perkara ini seakan menghadapi perkara yang pelik, Ketua Majelis yang mengupayakan perdamaian dengan menasehati Pemohon maupun mediator yang ditunjuk oleh Peradilan Agama untuk melakukan upaya mediasi agar mengurungkan keinginan Pemohon untuk menikah lagi pada akhirnya seakan berjalan sendiri dan dimentahkan oleh keterangan Termohon yang 
Al-‘adalah, Volume 22 Nomor 1 April 2019

menyatakan bahwasannya Termohon tidak keberatan kalau Pemohon menikah lagi (poligami) karena Termohon kurang mampu melayani kebutuhan biologis dan bahkan dalam bukti surat pernyataan Termohon juga menyatakan menyetujui Pemohon menikah lagi (Poligami), sebagaimana bukti P.6 dan antara Pemohon, Termohon dengan calon istri kedua Pemohon tidak ada hal-hal yang menghalanginya untuk menikah. Keterangan Termohon tersebut kemudian diperkuat oleh saksi Pemohon I dan saksi Pemohon II dalam keterangannya dihadapan Majelis Hakim bahwa saksi mengetahui dari Pemohon alasan Pemohon mengajukan poligami karena Termohon kurang bisa melayani hubungan batin Pemohon. Perkara yang tidak hanya didasari pada Pemohon mampu menjamin keperluan hidup istri-istri dengan penghasilan Pemohon, Pemohon sanggup berlaku adil terhadap istri-istrinya, akan tetapi juga karena masalah pemenuhan kebutuhan biologis yang tidak sempurna dilaksanakan oleh Termohon sudah terlalu lama (kondisi seperti ini berlangsung hingga Pemohon dan Termohon dikaruniai seorang anak) hal ini juga didukung oleh kedekatan Pemohon dengan calon istri kedua yang berstatus asal dan teman seprofesi dengan Pemohon sudah sangat akrab, saling cinta mencintai dan telah mengenal 2 tahun dengan calon istri kedua, sehingga Pemohon takut berbuat yang dilarang dalam ajaran agama Islam Pemohon.

Pada perkara lain Peradilan Agama Gresik pada tingkat pertama menangani perkara Pembatalan Penggugat atas Tergugat I, pada perkara Peradilan Agama meskipun memuat kata "Majelis Hakim telah berusaha mendamaikan Para pihak berperkara, dan Penggugat tetap pada pendiriannya untuk melanjutkan gugatannya" yang bisa diartikan bahwasannya usaha mendamaikan yang dilakukan oleh majelis hakim gagal atau tidak berhasil dan tidak dilanjutkan pada proses mediasi dengan menunjuk mediator sebagaimana yang ditetapkan oleh undang-undang akan tetapi pada keputusannya maejlis hakim berhasil memenangkan gugat Penggugat agar perkawinan yang dilakukan oleh Tergugat I dan Tergugat II dibatalkan meskipun hakim tetap memerintahkan Penggugat mengajukan bukti-bukti terlebih dahulu sebelum dibacakan keputusan Peradilan, dalam perkara yang diajukan Peradilan Agama ialah perkara a quo.

Peradilan Agama Mojokerto pada tingkat pertama menangani putusan dalam perkara cerai gugat yang diajukan oleh Penggugat dengan Tergugat. Berdasarkan saksi Penggugat I dan saksi Penggugat II yang memberikan keterangan bahwa semula rumah tangga Penggugat dan Tergugat hidup rukun, namun sejak 1 tahun yang lalu mulai terjadi perselisihan dan pertengkaran, karena pisah rumah; adalah karena masalah ekonomi, Tergugat banyak hutang tanpa sepengetahuan Penggugat dan Tergugat sering main judi serta minum-minuman keras yang akibatnya sering memukul Penggugat juga mengalami kegagalan dalam melakukan mediasi maupun mendamaian antara Penggugat maupun Tergugat, yang tetap pada pendiriannya masing-masing, perkara yang ditangani Peradilan Agama Sidoarjo ini juga Majelis Hakim mempertimbangkan terlebih dahulu kewenangan Peradilan Agama memeriksa, 
Moh. Ali, Urgensi Politik dan Implementasi Maslahah...

mengadili, dan memutus perkara a quo sebagaimana yag terjadi di Peradilan Agama Gresik.

\section{Tranformasi Islah Dan Tahkim Ke Dalam Mediasi}

Proses tahkim dalam mediasi yang dilakukan Peradilan agama ialah dengan cara menghadirkan pihak-pihak yang berperkara untuk, tidak hanya membicarakan masalah yang sedang terjadi, akan tetapi juga akar dari permasalahan dan membuat perkiraanperkiraan tentang solusi yang tidak hanya bisa selesai dalam persidangan saja akan tetapi juga membawa kebermanfaatan bagi pihak-pihak yang bersengketa.

Di Peradilan Agama upaya islah dan tahkim dalam mediasi berjalan sangat alot. Peradilan Agama dalam melaksanakan mediasi menerapkan prinsip dasar sebagai berikut $^{6}$, Prinsip Kerahasiaan, Prinsip Sukarela, Prinsip Pemberdayaan, Prinsip Netralitas

Peradilan Agama menggunakan model facilitative mediation ${ }^{7}$ dalam mediasi, yakni mediasi yang tujuan utamanya untuk menghindarkan para pihak yang bersengketa dari posisi mereka dan menegosiasikan kebutuhan dan kepentingan para pihak dari hak-hak legal mereka secara kaku.

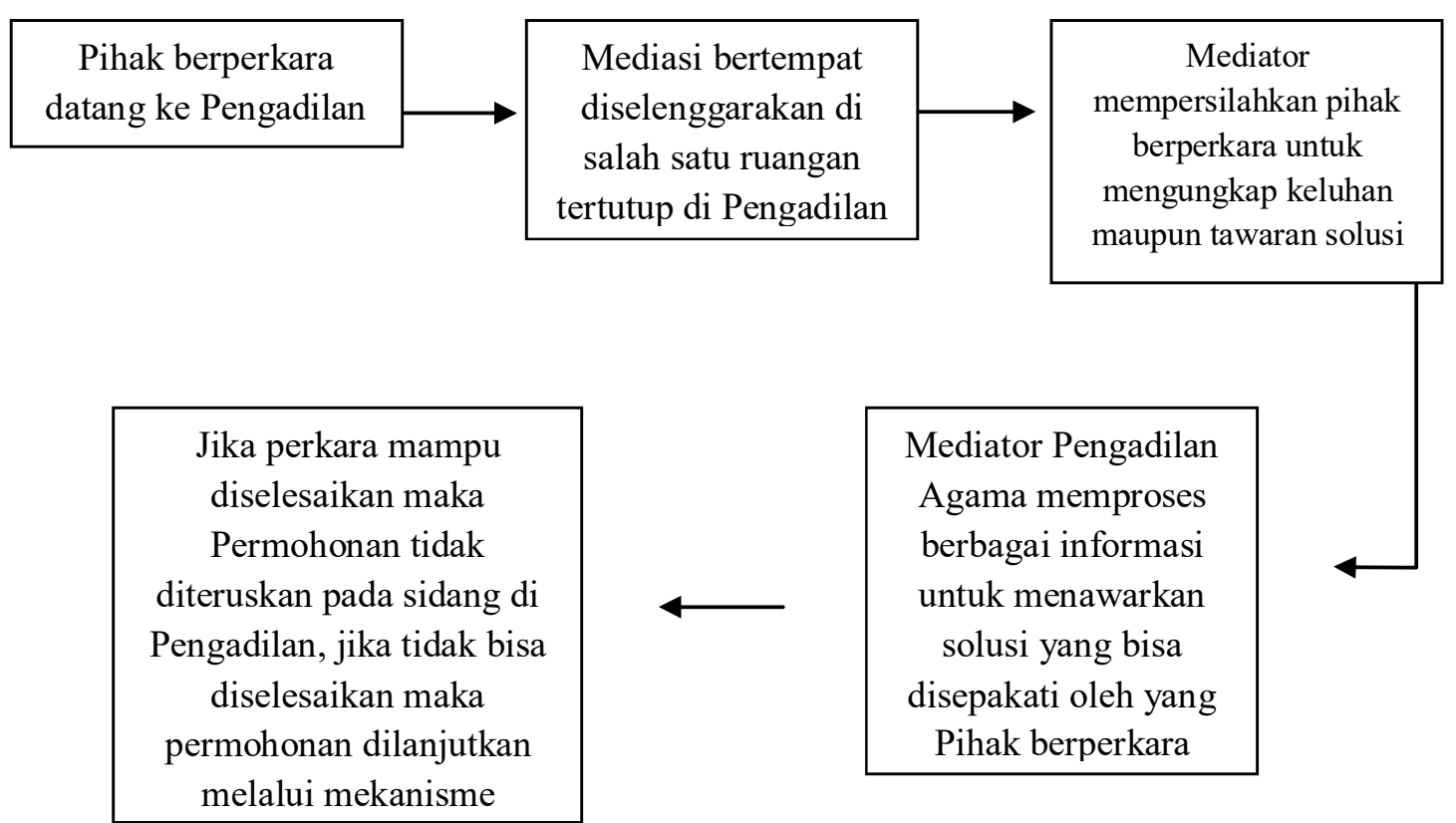

Model ini digunakan mediator dikarenakan kedua belah pihak yang berperkara memiliki pendapat masing-masing dan mengandung sejumlah prinsip sebagai berikut: Dengan memilih dan memilah permasalahan yang terjadi setelah itu mendatangkan

'Syahrizal Abbas, Mediasi dalam Persfektif Hukum Syariah, Hukum Adat, dan Mediasi Nasional, (Jakarta: Kencana, 2009), 28-30.

${ }^{7}$ Syahrizal Abbas, Mediasi dalam Persfektif Hukum Syariah, Hukum Adat, dan Mediasi Nasional, (Jakarta: Kencana, 2009), 33. 
Al-'adalah, Volume 22 Nomor 1 April 2019

pihak yang berperkara untuk melakukan mediasi; penekanan mediasi lebih ditujukan kepada kebutuhan dan kepentingan para pihak yang berselisih, meingingat pihak-pihak yang berperkara mengajukan berbagai keluhan tentang permasalahan yang dihadapi, maka pihak mediator ketika akan menawarkan solusi tentu memperhatikan kedua belah pihak yakni dengan menasehati kedua pihak agar saling memaafkan satu sama lain. Mediator mengarahkan para pihak dari positional negotiation ke interest based negotiation yang mengarahkan kepada penyelesaian yang saling menguntungkan yakni dengan mengharapkan kedua belah pihak yang berperkara saling melakukan instropeksi; mediator mengarah para pihak untuk lebih kreatif dalam mencari alternatif penyelesaian sengketa dengan cermat, teliti, dan tidak terburu-buru dalam melakukan pekerjaan; mediator perlu memahami proses dan teknik mediator tanpa harus ahli dalam bidang yang diperselisihkan memperbaiki hubungan silahturahim serta mendorong berbagai pihak untuk membantu penyelesaian konflik.

Peradilan Agama dalam upaya menyelesaikan perkara yang diajukan menggunakan model transformative mediation, dengan menggunakan mediasi semacam ini mediasi bertujuan untuk mencari kesepakatan hak-hak legal yang bisa diantisipasi oleh mediator Peradilan Agama yang penulis jabarkan dalam gambar dibawah ini:

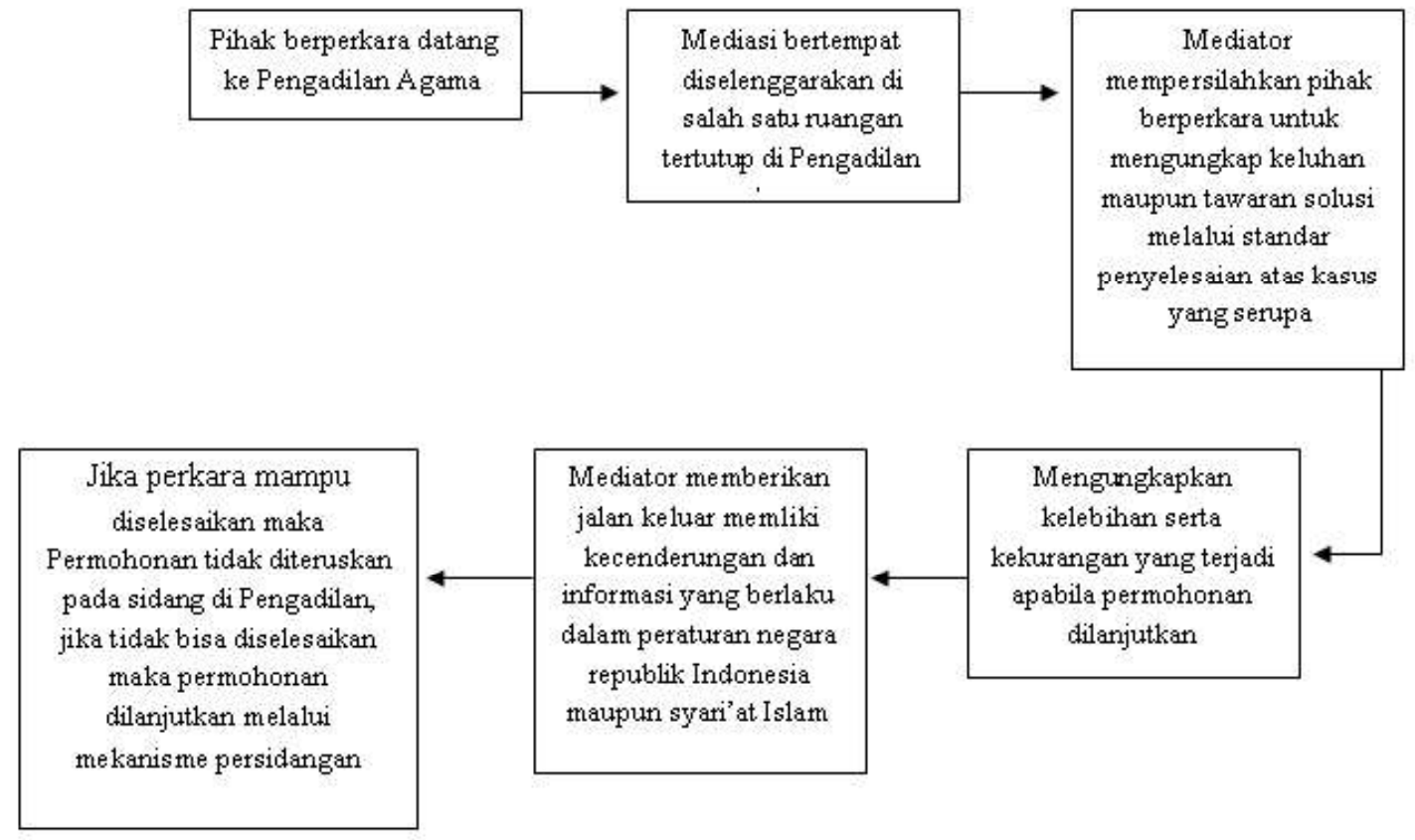

Mediator dalam menjalankan mediasi juga meberikan informasi, saran, persuasi kepada pihak-pihak yang berperkara mengandung sejumlah prinsip sebagai berikut ${ }^{8}$ : Para pihak berharap bahwa mediator akan menggunakan keahlian dan pengalamannya untuk mengarahkan penyelesaian sengketa pada prediksi serta rekonsialisasi antara para

'Syahrizal Abbas, Mediasi dalam Persfektif Hukum Syariah, Hukum Adat, dan Mediasi Nasional, (Jakarta : Kencana, 2009), 34-35. 
Moh. Ali, Urgensi Politik dan Implementasi Maslahah...

pihak berperkara untuk mengurungkan niatan permohonan pengajuan ijin menikah lagi (poligami); dalam pertimbangan ketika mengajukan usulan penyelesaian perkara mediator Peradilan Agama memfokuskan kepada hak pihak yang berperkara dalam tawaran solusi atas penyelesaian masalah melalui standar penyelesaian atas perkara yang serupa; dengan mengungkapkan kelebihan serta kekurangan yang terjadi saat poligami nantinya benar-benar dilaksanakan oleh Pemohon dan akibat apa yang akan didapatkan oleh anak maupun Termohon; mediator dalam memberikan jalan keluar memliki kecenderungan dan informasi yang berlaku dalam peraturan negara republik Indonesia maupun syariat Islam guna mengarahkan para pihak berperkara menuju suatu hasil akhir yang pantas dan dapat diterima oleh Pemohon serta Termohon

Dalam sebuah perkara, upaya islah dan tahkim dengan cara mendamaikan, menasehati Pemohon agar mengurungkan keinginannya untuk menikah lagi yang dilakukan Majelis Hakim pada hari sidang ditentukan antara Pemohon (suami) dengan Termohon (istri) tidak berhasil begitupun juga islah dan tahkim yang intinya berrtujuan agar Pemohon tidak berpoligami melalui upaya mediasi melalui mediator, dalam mediasi baik pemohon maupun termohon sama-sama dalam pendirian masing-masing, Pemohon yang berkeinginan cerai dengan Termohon sedangkan Termohon ingin kembali rukun dengan Pemohon dikarenakan anak-anak hasil perkawinan mereka masih membutuhkan sosok orang tua yang utuh dan permasalahan yang berlarut-larut, sehingga baik usaha yang dilakukan oleh mediator maupun Majelis Hakim dengan cara menasehati pihak yang berperkara maupun upaya mediasi yang disediakan oleh pihak Peradilan Agama mengalami kegagalan.

\section{Implikasi Mediasi Dalam Perspektif Maslahah}

Berdasar segi dalil yang digunakan pada saat beralih dari qiyas, macam isithsan yang digunakan oleh Peradilan Agama, yakni mediator beralih dari apa yang dituntut (qiyas jali) menjadi apa yang dikehendaki oleh Pemohon maupun Termohon (qiyas khafi). Hal ini dikarenakan baik dari Pemohon maupun Termohon memiliki pendapat sendiri tentang masalah yang tengah dihadapi hal ini digunakan agar penyelesaian perkara dapat lebih mudah tercapai.

Sedangkan istihsan yang digunakan Peradilan Agama Surabaya dalam upaya memediasi antara pihak yang berperkara dengan mengacu kaidah yang umumnya digunakan oleh kalangan ulama' Hanafiyah yakni,

$$
\text { العمل بالإجتهد وغا لب الرأى فى تقدير ما جعله الشرع موكولا إلى أراينا }
$$

Artinya : "Beramal dengan berijtihad dan umum pendapat dalam menentukan sesuatu yang syara' yang menyerabkannya kepada pendapat kita"

Hal ini digunakan dikarenakan Pemohon yang tetap bersikukuh agar permohonan cerainya dapat dikabulkan oleh Peradilan Agama dengan mengajukan berbagai argumen, sedangkan pihak termohon juga tetap pada pendiriaannya dengan berbagai 
argumen yang diajukan untuk menruskan bahtera rumah tangga yang selama ini mereka bina.Keputusan yang dikeluarkan oleh Peradilan Agama tidak saja melihat apa keluhan dari Pemohon akan tetapi juga mempertimbangkan apa yang telah diperbuat oleh Pemohon kepada Termohon; pada tingkat kebutuhannya maslahah yang ada dalam mediasi Al-Maslahah al-Hajiyyah (kemaslahatan sekunder) ialah sesuatu yang diperoleh oleh seseorang untuk memudahkan untuk menjalani hidup dan menghilangkan kesulitan dalam rangka memelihara memelihara agama, memelihara jiwa, dan memelihara akal, maka keputusan yang diambil oleh Peradilan Agama dalam konpensi Mejelis hakim menimbang, bahwa berdasarkan fakta tersebut diatas, Majelis Hakim berkesimpulan dan berkeyakinan bahwa rumah tangga Suami dan Istri benarbenar telah terjadi perselisihan dan pertengkaran yang berlarut-larut serta sulit untuk disatukan kembali sebagai suami istri, rumah tangga yang sudah tidak harmonis dan tidak dilandasi rasa cinta mencintai dan hati masing-masing telah pecah, berpendapat bahwa perselisihan dan pertengkaran antara Suami dan Istri dikarenakan kesalahankesalahan yang ditimbulkan oleh masing-masing pihak, maka berdasarkan Yurisprudensi MARI No 266 K/AG/1993 tertanggal 03 Juni 1994 diangkat sebagai abstrak hukum bahwa perceraian dengan adanya perselisihan dan pertengkaran secara terus menerus tanpa mempersoalkan siapa yang salah dan apa penyebabnya. Maka majelis hakim memutuskan untuk mengabulkan permohonan Suami, memberi izin kepada Suami untuk menjatuhkan talak satu raj'i terhadap Istri di depan sidang Peradilan Agama, memerintahkan kepada Panitera Peradilan Agama Surabaya untuk mengirimkan salinan penetapan ikrar talak kepada pegawai pencatat nikah kantor urusan agama kecamatan yang mewilayahi tempat tinggal Pemohon dan Termohon serta tempat perkawinan dilangsungkan untuk dicatat. Untuk kandungan hasil keputusan mediasi yang dinyatakan gagal dan diteruskan pada akibat hukum dikabulkannya permohonan cerai Pemohon ialahh Al-Maslahah al-Khassab (maslahah khusus/ pribadi), yang berkenaan dengan orang-orang tertentu', majelis hakim berpendapat perceraian ini adalah kehendak Suami dan Istri serta tidak masuk kategori nuzyus (Vide pasal 83 dan 84 Kompilasi Hukum Islam), maka sesuai pasal 149 huruf (a) jo pasal 158 huruf (b) Kompilasi Hukum Islam dan sesuai dengan penghasilan dalam permusyawaratannya, mejelis hakim memutuskan rekonpensi untuk menghukum pihak suami untuk memberikan nafkah iddah sebesar Rp. 7.500.000,- tujuh juta lima ratus ribu rupiah) dan Mut'ah berupa uang sebesar Rp. 20.000.000,- (dua puluh juta rupiah) kepada istri.

Peradilan Agama juga menerapkan kandungan Al-Maslahah al-Khassah (maslahah khusus/ pribadi), yang berkenaan dengan orang-orang tertentu ${ }^{10}$ yakni kedekatan Pemohonn dengan wanita lain yang berstatus janda dan teman kerja Pemohon, serta mengingat proses mediasi yang sudah digelar digelar oleh Peradilan Agama melalui

${ }^{9}$ Asmawi, Teori Maslahat dan Relevansinya dengan Perundang-undangan Pidana Kusus di Indonesia, (Jakarta: dalam Litbang dan Diklat Kementrian Agama RI, 2010), 54-55.

${ }^{10} \mathrm{Ibid}$., Asmawi, Teori Maslahat ....., 54-55. 
Moh. Ali, Urgensi Politik dan Implementasi Maslahah...

mediator atau yang berkenaan dengan keputusan pemohon untuk melakukan poligami menghasilkan kegagalan dengan adanya ketetapan hati dari Pihak Pemohon untuk tetap menikah lagi maupun kepasrahan Termohon untuk mengijinkan Pemohon menikah lagi karena tidak mampu melayani kebutuhan biologis pemohon, namun mediator menciptakan opsi-opsi untuk menemukan butir kesepakatan dan merumuskan keputusan untuk nantinya diajukan dalam persidangan karena mediasi ini dinilai gagal, didasarkan tingkat kebutuhannya mediasi yang dilakukan oleh Peradilan Agama masuk kategori Al-Maslahah al-Daruriyah (kemaslahatan primer) ialah kemaslahatan yang berhubungan dengan kebutuhan pokok umat manusia di dunia dan di akhirat. Kemaslahatan ini, terdiri atas lima yaitu: memelihara agama, memelihara jiwa, memelihara akal, memelihara keturunan, dan memelihara harta.

Pada perkara lain yang terjadi Implikasi Mediasi Dalam Perspektif Maslahah di Peradilan Agama dari segi kandungan usaha yang dilakukan Peradilan Agama Gresik untuk tidak melanjutkan pada upaya mediasi ialah Al-Maslahah al-'Ammah (maslahah umum) yang berkaitan dengan kepentingan orang banyak. Kemaslahatan umum itu tidak berarti untuk kepentingan semua orang, tetapi bisa berbentuk kepentingan mayoritas umat atau kebanyakan umat ${ }^{11}$ yakni agar setiap warga negara taat akan peraturan yang telah berlaku, selain itu upaya Majelis Hakim menasehati Penggugat dan Tergugat berdasarkan tingkat kebutuhan maslahah maka upaya tersebut masuk dalam Al-Maslabah Tahsiniyah (kemaslahatan tersier) ialah seseorang yang memelihara agama, memelihara jiwa, memelihara akal, memelihara keturunan, dan memelihara harta melakukannya dengan cara meraih dan menetapkan hal-hal yang pantas dan layak dari kebiasaan-kebiasaan hidup yang layak dari kebiasaan-kebiasaan hidup yang baik, serta menghindarkan sesuatu yang dipandang sebaliknya oleh akal.

Peradilan Agama ketika memutuskan hanya melakukan upaya menasehati Penggugat maupun Tergugat agar tidak bercerai dan tidak melakukan mendamaikan dengan mendasarkan pada kebutuhan akan pemeliharaan agama, jiwa, akal, keturunan serta harta (Al-Maslahah al-Daruriyah) maupun menjadi katalisator agar Penggugat menjadi mudah untuk menjalani hidup dan menghilangkan kesulitan yang selama ini ia hadapi ketika menjalani perkawinan dengan Tergugat (Al-Maslahah al-Hajizyah) dan menetapkan dasar Perlindungan terhadap jiwa, hikmah keberadaan syariah dengan aturannya melindungi jiwa manusia agar terhindar dari kezaliman orang lain, ${ }^{12}$ mengakibatkan Majelis Hakim memutuskan untuk tidak melanjutkan upaya menasehati yang dilakukan terhadap Penggugat maupun Tergugat pada mediasi ialah dalam kerangka 'memenangkan' gugatan cerai penggugat (istri), sebagai bentuk perlindungan negara (melalui Peradilan Agama sebagai pihak yang berwenang) terhadap warga negara, terlebih lagi perempuan, yang tersakiti; bahkan dalam pembacaan gugatan cerai ini pihak Peradilan Agama melandaskan perlindungan terhadap kehormatan manusia, karena manusia adalah mahluk mulia, kehormatanya senantiasa dijaga dan dilindungi

${ }^{11}$ Narun Haroen, Ushul Fiqih 1, (Jakarta: Logos 1996), 116.

${ }^{12}$ Hamzah Ya'kub, Pengantar Ilmu Syariah Hukum Islam, (Bandung: CV. Diponegoro, 1995), 48. 
Al-‘adalah, Volume 22 Nomor 1 April 2019

oleh syariah, ${ }^{13}$ sehingga pembacaan putusan gugatan cerai ini dilakukan dalam sidang tertutup yang otomatis tidak bisa sembarangan dihadiri oleh pihak-pihak yang tidak berkepentingan dalam perkara ini.

Secara umum dari segi keberadaan maslabah yang digunakan Peradilan Agama menurut syara' ialah Al-Maslabah Al-Mu'tabarah yakni, maslabah yang secara tegas diakui oleh syariat dan telah ditetapkan ketentuan-ketentuan hukum untuk merealisasikan sebagai berikut:

a. Dengan menyegerakan terlaksannya gugatan cerai penggugat (istri), sebagai bentuk perlindungan negara (melalui Peradilan Agama sebagi pihak yang berwenang) terhadap warga negara, terlebih lagi perempuan yang tersakiti dan kandungan mediasinya termasuk dalam Al-Maslahah al-'Ammah (maslahah umum) yang berkaitan dengan kepentingan orang banyak yakni agar setiap warga negara taat akan peraturan yang telah berlaku, mendasarkan pada kebutuhan akan pemeliharaan agama yang berarti alasan gugatan cerai Penggugat tersebut telah memenuhi alasan perceraian sebagaimana ketentuan Pasal 19 huruf f Peraturan Pemerintah Nomor 9 Tahun 1975 tentang Pelaksanaan undang-undang Nomor 1 Tahun 1974 tentang Perkawinan juncto Pasal 116 huruf f Kompilasi Hukum Islam akhirnya memutuskan petitum menceraikan perkawinan Penggugat dan Tergugat tersebut patut dikabulkan, karena dari fakta pula dapat disimpulkan bahwa perkawinan Penggugat dan Tergugat telah pecah dan tidak mungkin dipertahankan karena justru akan menimbulkan beratnya penderitaan dan mudlarat kedua belah pihak.

b. Perlindungan terhadap jiwa, hikmah keberadaan syariah dengan aturannya melindungi jiwa manusia agar terhindar dari kezaliman orang lain ${ }^{14}$, sebagai contoh kedekatan Pemohon dengan wanita lain yang berstatus janda sekaligus teman kerja Pemohon dan Termohon yang mengijinkan Pemohon menikah lagi karena tidak mampu melayani kebutuhan biologis bersifat (Maslahah al-Daruriyah). Namun dalam kandungan keputusannya Peradilan Agama lebih menitik beratkan pada Al-Maslahah al-Khassah yakni berkenaan dengan orang-orang tertentu, sehingga memandang persyaratan untuk beristri lebih dari seorang sebagaimana tercantum dalam pasal 5 ayat 1 Undang-Undang nomor 1 tahun 1974 tentang perkawinan Jo. Pasal 58 ayat 1 Kompilasi Hukum Islam (KHI) telah dipenuhi oleh Pemohon, telah terpenuhi maksud pasal 4 ayat (1) dan pasal 5 Undangundang No.1 tahun 1974 Jo. Pasal 56, 58 Kompilasi Hukum Islam, dengan memperhatikan Firman Allah dalam Al-Qur'an surat An - Nisa' ayat 3.

c. Keberadaan syariah ialah melindungi akal pikiran supaya ia tetap sehat dan berfungsi dengan baik. Segala perkara yang dapat merusak kesehatan akal harus disingkirkan ${ }^{15}$, mediator Peradilan Agama yang mengalihkan dari apa yang

${ }^{13}$ Hamzah Ya'kub, Pengantar Ilmu Syariah (Hukum Islam), 46.

${ }^{14}$ Hamzah Ya'kub, Pengantar Ilmu Syariah Hukum Islam, (Bandung: CV. Diponegoro, 1995), 48.

${ }^{15}$ Zainuddin Ali, Hukum Islam Pengantar Ilmu Hukum Islam di Indonesia, (Jakarta: Sinar Grafika, 
Moh. Ali, Urgensi Politik dan Implementasi Maslahah...

dituntut (qiyas jali) menjadi apa yang dikehendaki oleh Pemohon maupun Termohon (qiyas khafi). Hal ini dikarenakan baik dari Pemohon maupun Termohon memiliki pendapat sendiri tentang masalah yang tengah dihadapi. Menjadi katalisator agar Penggugat dan tergutgat menjadi mudah untuk menjalani hidup dan menghilangkan kesulitan yang selama ini pihak yang berperkara hadapi dan masalah yang berlarut-larut yang dihadapi pihak akan menyulitkan siapa saja untuk mewujudkan jalan perdamaian.

Pada tingkat kebutuhan maslahah yang ada dalam mediasi mediator maupun Majelis Hakim berkesimpulan dan berkeyakinan bahwa rumah tangga Suami dan Istri benar-benar telah terjadi perselisihan dan pertengkaran yang berlarut-larut serta sulit untuk disatukan kembali sebagai suami istri, rumah tangga yang sudah tidak harmonis dan tidak dilandasi rasa cinta mencintai dan hati masing-masing telah pecah, berpendapat bahwa perselisihan dan pertengkaran antara Suami dan Istri dikarenakan kesalahan-kesalahan yang ditimbulkan oleh masing-masing pihak digolongkan pada Al-Maslahah al-Hajiyyah (kemaslahatan sekunder). Sedangkan kandungan hasil keputusan mediasi (yang dinyatakan gagal) dan diteruskan pada akibat hukum dikabulkannya permohonan cerai Pemohon termasuk dalam AlMaslahah al-Khassah (maslahab khusus/ pribadi), yang berkenaan dengan orangorang tertentu ${ }^{16}$, majelis hakim berpendapat perceraian ini adalah kehendak Suami dan Istri serta tidak masuk kategori nusyus (Vide pasal 83 dan 84 Kompilasi Hukum Islam), maka sesuai pasal 149 huruf (a) jo pasal 158 huruf (b) Kompilasi Hukum Islam dan sesuai dengan penghasilan dalam permusyawaratannya mejelis hakim memutuskan rekonpensi untuk menghukum pihak suami untuk membayar nafkah iddah kepada istri.

d. Perlindungan terhadap kehormatan manusia, karena manusia adalah mahluk mulia, kehormatanya senantiasa dijaga dan dilindungi oleh syariah, ${ }^{17}$, sebagaimana dalam posita Penggugat telah memberikan identitas yang salah kepada Pegawai Pencatat Nikah KUA Kecamatan Ujung Pangkah, Kabupaten Gresik (AlMaslabah Tabsiniyah), adanya bukti pula penikahan yang dilangsungkan oleh Penggugat dan Tergugat I adalah poligami yang tidak memenuhi syarat dan prosedur hukum yang berlaku yang diawali dengan pemberian identitas yang salah oleh Penggugat dalam pengurusan administrasi perkawinannya di Kantor Urusan Agama, sehingga Peradilan Agama membuat keputusan pembatalan pernikahan Penggugat dengan Tergugat I yang dinilai a quo (Al-Maslahah al-'Ammah), maka Surat Kutipan Akta Nikah Nomor: 009/09/I/2011 tertanggal 13 Januari 2011yang dikeluarkan oleh Pegawai Pencatat Nikah Kantor Urusan Agama Kecamatan Ujung Pangkah, Kabupaten Gresik, dinyatakan tidak berlaku dan tidak

2006), 12.

${ }^{16}$ Asmawi, Teori Maslabat dan Relevansinya dengan Perundang-undangan Pidana Kusus di Indonesia, (Jakarta: dalam Litbang dan Diklat Kementrian Agama RI, 2010), 54-55.

${ }^{17}$ Hamzah Ya'kub, Pengantar Ilmu Syariah (Hukum Islam), 46. 
Al-‘adalah, Volume 22 Nomor 1 April 2019

mempunyai kekuatan hukum, memerintahkan kepada TERGUGAT II ASLI Kecamatan Ujung Pangkah, Kabupaten Gresik untuk mencatat pembatalan pernikahan antara Penggugat (PENGGUGAT ASLI) dengan Tergugat I (TERGUGAT I ASLI) sebagaimana dalam Akta Nikah Nomor: 009/09/I/2011 tanggal 13 Januari 2011.

Dengan kata lain, beberapa hal yang harus menjadi titik perhatian dan penegasan hukum terutama dalam lingkup mediasi dalam hal ini melalui sudut pandang kemaslahatan,. Tidak kurang dari beberapa poin berikut:

1) Dengan menyegerakan terlaksannya gugatan cerai penggugat (istri), sebagai bentuk perlindungan negara (melalui Peradilan Agama sebagi pihak yang berwenang) terhadap warga negara, terlebih lagi perempuan yang tersakiti karena karena dari fakta pula dapat disimpulkan bahwa perkawinan Penggugat dan Tergugat telah pecah dan tidak mungkin dipertahankan karena justru akan menimbulkan beratnya penderitaan dan mudlarat kedua belah pihak. Hal ini dilakukan agar setiap warga negara taat akan peraturan yang telah berlaku.

2) Perlindungan terhadap jiwa, hikmah keberadaan syariah dengan aturannya melindungi jiwa manusia agar terhindar dari kezaliman orang lain, dengan mengijinkan Pemohon menikah lagi karena Termohon tidak mampu melayani kebutuhan biologis bersifat.

3) Keberadaan syariah ialah melindungi akal pikiran supaya ia tetap sehat dan berfungsi dengan baik. Segala perkara yang dapat merusak kesehatan akal harus disingkirkan dengan menjadi katalisator agar pihak berperkara menjadi mudah untuk menjalani hidup dan masalah yang berlarut-larut maupun menghilangkan kesulitan yang selama ini dihadapi pihak berperkara yang akan menyulitkan siapa saja untuk mewujudkan jalan perdamaian.

4) Perlindungan terhadap kehormatan manusia, karena manusia adalah mahluk mulia, kehormatanya senantiasa dijaga dan dilindungi oleh syariah dengan membuat keputusan pembatalan pernikahan untuk Penggugat yang telah memberikan identitas yang salah kepada Pegawai Pencatat Nikah KUA.

\section{Kesimpulan}

Hasil penelitian ini adalah orientasi kaidah-kaidah tentang mediasi dan implikasinya terhadap penyelesaian perkara perdata di Peradilan Agama. Dengan demikian, studi ini sangat urgen untuk dilakukan, baik dilihat dari fokus, obyek, dan alat analisis, maka ditemukan sebagai berikut:

a. Landasan yuridis-filosofis yang diintegrasikan mediasi dalam proses beracara di Peradilan Agama ialah dengan berlandaskan pada PERMA No. 1 Tahun 2008, mediator Peradilan Agama kemudian mengintegrasikan pada model mediasi facilitative mediation karena kedua belah pihak yang berperkara memiliki pendapat masing-masing serta bersikukuh pada pendapat tersebut dan transformative mediation bertujuan untuk mencari kesepakatan hak-hak legal yang bisa diantisipasi oleh 
Moh. Ali, Urgensi Politik dan Implementasi Maslahah...

mediator.

b. Mediasi yang dilakukan Peradilan Agama tidak hanya membicarakan masalah yang sedang terjadi, tetapi juga akar dari permasalahan dan membuat perkiraanperkiraan tentang solusi yanng tidak hanya bisa selesai dalam persidangan saja tetapi juga membawa kebermanfaatan bagi pihak-pihak yang berselisih. Disamping itu manfaat penerapan mediasi dapat memperbaiki hubungan silahturahim serta mendorong berbagai pihak untuk membantu penyelesaian perselisihan, menghindarkan manusia dari tindak kekerasan, menstimulus berbagai pihak untuk cermat, teliti, dan tidak terburu-buru dalam melakukan pekerjaan; tekun, memliki keteguhan hati tabah dalam mencapai tujuan, sistematis dan tabah dalam mengubah diri kearah yang lebih baik.

c. Secara umum pengintegrasian mediasi dalam proses beracara di Peradilan Agama dalam perspektif maslahah, dari segi keberadaan maslahah, dengan memanfaatkan Al-Maslahah Al-Mu'tabarah yaitu, maslahah yang secara tegas diakui oleh syariat dan telah ditetapkan ketentuan-ketentuan hukum yang direalisasikan sebagaimana diterangkan di pembahasan.

\section{DATAR PUSTAKA}

Abbas Syahrisal, Mediasi dalam Hukum Syariah, Hukum Adat, \& Hukum Nasional, (Jakarta: Kencana, 2011)

Abbas Syahrizal, Mediasi dalam Persfektif Hukum Syariah, Hukum Adat, dan Mediasi Nasional, (Jakarta: Kencana, 2009)

Ali Zainuddin, Hukum Islam Pengantar Ilmu Hukum Islam di Indonesia, (Jakarta: Sinar Grafika, 2006).

Ali Zainuddin, Metode Penelitian Hukum, (Jakarta: Sinar Grafika, 2009)

al-Shatibi Abu Ishaq, al-Muwafaqat fi Usul al-Shari'ah, (Beirut: Dar al-Kutub al-Ilmiyah, 2004)

Asmawi, Teori Maslahat dan Relevansinya dengan Perundang-undangan Pidana Kusus di Indonesia, (Jakarta: dalam Litbang dan Diklat Kementrian Agama RI, 2010)

Haroen Narun, Ushul Fiqih 1, (Jakarta: Logos 1996)

Redissi Hamadi dan Jon-Erik Lane, "Does Islam Partivide a Theory of Violence", dalam Amelie Blom, Laetitia Bucaille Dab Luis Martinez, The Enigma of Iaslamits Violence, (New York: Columbia University Press, 2007)

Soekanto Soerjono dan Sri Mamudji, Penelitian Hukum Normatif Suatu Tinjauan Singkat, (Jakarta: Rajawali Press, 1999)

Usman Suparman, Hukum Islam: Asas-asas dan Pengantar Studi Hukum Islam dalam Tata Hukum Indonesia, (Jakarta: Gaya Media Pratama, 2001)

Ya’kub Hamzah, Pengantar Ilmu Syariah Hukum Islam, (Bandung: CV. Diponegoro, 1995)

Yuliana I Nengah, Kompilasi Perundang-undangan Hukum Acara Peradilan dan Undan-undang Penegakan Hukum di Indonesia, 2004. 